\title{
Exploring the potential of visual shadowing as an L2 listening pedagogy at universities in Japan
}

\author{
Fuyu Shimomura
}

Department of English Studies, Kyoto Women's University, Japan

https://doi.org/10.36505/ExLing-2018/09/0025/000358

\begin{abstract}
Since MEXT announced the "Action plan for educating global citizens with high English competence" in 2003, universities in Japan are expected to improve student English communication competence. However, many Japanese students tend to struggle with listening to English sentences. Given this inclination, some scholars pointed out the effectiveness of repeating, visual shadowing and shadowing practices as a SLA listening pedagogy. This paper explores how visual shadowing activity helps students listen to English better with using student TOEIC listening scores, and interview data with case study students. (85 words)

Key words: shadowing, listening pedagogy, EFL, university, Japan
\end{abstract}

\section{Background}

MEXT (Ministry of Education, Culture, Sports, Science, and Technology) announced two English education policy changes in 1998 and 2003, regarding what higher educational institutions should be responsible for teaching to college students. The "Action Plan for educating global citizens with high English competence" announced in 2003 specifies that universities should develop student English skills to the level where they feel comfortable communicating (MEXT, 2003). In addition, MEXT (2003) also states that they should use English proficiency test such as TOEIC, TOEFL and IELTS as valid measures of student English competence.

However, Richards (1983) points out that Japanese EFL learners tend to be challenged with listening, particularly at the perception stage (bottom-up processing). Osuka (2008) further clarifies that particularly their inabilities to perceive 1) fast speeches and 2) particular English sounds or phonemes are the two major impairing factors for Japanese learners. In other words, if Japanese EFL learners have access to the pedagogies that help them overcome these two impairing factors, their listening perception skills should significantly improve. To achieve this end, shadowing has potentials to help learners increase their articulation rates and contributes to developing better L2 listening abilities by helping working memory more effectively hold and process the auditory

ExLing 2018: Proceedings of 9th Tutorial and Research Workshop on Experimental Linguistics, 28-30 August, Paris, Frannce 
information entering the phonological loop (Hamada, 2017; Kadota, 2012 \& 2015; Tamai, 2002 \& 2005). Taken together, it is possible to claim that shadowing has potentials to improve learners' phoneme perception skills as well as the articulation/subvocal rehearsal rate, which determines the speed and amount of information learners could process within the time limitation of working memory. Therefore, this research explores how differences in articulation rates influence learners' L2 lisning skills improvement.

\section{Research methods}

Purpose. Given the claim that shadowing and similar outputting activities including visual shadowing are helpful in terms of improving listening skills in L2, and that inability to understand fast speech and particular English sounds or phonemes are the two major impairing factors for Japanese EFL students, this paper aims to explore how difference in articulation rate for fast-paced visual shadowing influences the improvement of student listening skills in English. An independent variable for this research inquiry is differences in articulation rates (Group A: slower, Group B: faster) for shadowing activities with texts (=visual shadowing), and two dependent variables are differences in: 1) TOEIC listening score increase, and 2) the increases in WPM (=articulation rate) in visual shadowing TOEIC listening scripts between pre- and post-tests.

Participants. The participants were 65 non-English major freshmen enrolled in a private women's college, taking mandatory TOEIC preparation classes with the author. Both classes include repeating and visual shadowing (shadowing with texts) activities for the same time duration and same frequency.

Materials for visual shadowing. As the classes the author conducted researches in were mainly designed to prepare students for TOEIC tests, both slower and faster visual shadowing groups used TOEIC preparation materials as textbooks. Group A (slower visual shadowing group) used an unofficial TOEIC preparation material, while Group B (faster visual shadowing group) used one of the official TOEIC preparation materials published by ETS. Group A's textbook covered only the conversation and narration parts (Parts 3 and 4), while Group B's listening textbook covered all listening parts of the TOEIC exam (Part 1 through Part 4).

Procedures. First, students took TOEIC IP tests (pre-test). To examine if the articulation rates of visual shadowing influenced the development 
of listening skills or not, students were divided into two groups (Groups A \& B) based on their majors. Both groups had repeating practices at the same articulation rate and fast-paced visual shadowing at different articulation rates (Group A: slower, Group B: faster). After working on these activities for ten consecutive weekly class sessions, students took TOEIC IP test (post-test) again. The author also conducted pre- and post- interviews with randomly chosen six case study students from each group to explore: 1) if they perceived any changes in the way they perceive or understand English speech after working on rapid visual shadowing for the consecutive 10 weeks, and 2) if there were any differences observed in the articulation rates between pre- and postinterviews when they read aloud the exact same TOEIC listening scripts.

\section{Results}

An independent variable for this research inquiry is difference in articulation rate (Group A: slower, Group B: faster) for visual shadowing, and two dependent variables are differences in: 1) the increase in TOEIC listening score, and 2) the increase in WPM (=articulation rate) in visual shadowing TOEIC listening scripts between pre- and post-tests. Comparing listening score increases in Groups A and $\mathrm{B}$ highlighted that there are minor differences in the score increase (approximately by five points) between Groups A and B. (See Table 1). Although, Group B - the faster articulation group - showed a slightly bigger increase in mean score than Group A, this difference (5 points) in mean score increases should not be considered significant.

Table 1: Improvement of listening scores after shadowing for 10 weeks.

\begin{tabular}{|l|l|l|}
\hline \hline & Group A (slower) & Group B (faster) \\
\hline Pre-test listening score & 232.79 & 238.5 \\
\hline $\begin{array}{l}\text { Mean L score increase (dependent } \\
\text { variable) }\end{array}$ & 39.3 & 44.1 \\
\hline $\begin{array}{l}\text { Standard Deviation } \\
\text { (of L score increases) }\end{array}$ & 43.5 & 51.1 \\
\hline L-score increase range & -55 to 95 & -60 to 165 \\
\hline
\end{tabular}

Cross analysis of interview data sets with listening test score also highlighted the following two points: 1) those who worked hard to increase their articulation rates tend to increase their listening scores much bigger than those who worked hard to master the correct prosody, and 2) shadowing is also helpful for higher proficient learners. These research results indicate that when working on shadowing activities for 
improving listening skills, learners need to focus more on their articulation rates than their prosody, and also shadowing has a potential to help higher proficient learners improve their L2 listening skills as well.

\section{Conclusion}

Given these research findings, it became clear that 1) visual shadowing is helpful for learners of both higher and of lower proficiency - the difference to note is that lower proficient learners were less likely and higher proficient learners were more likely to feel their improvement in listening, and 2) students' fast articulation rates matter more to their listening skill improvement than mastering correct prosody, including sound changes or reductions in fast speeches. For providing more effective EFL listening pedagogies, exploring: 1) how much students should care about prosody while visual shadowing to improve their listening comprehension, 2) how fast students should be able to articulate English words or sentences to feel comfortable in listening to the English speech at the natural speed, and 3) whether TOEIC should be considered as a valid measure for listening comprehension, are the three major further avenues for investigation.

\section{References}

Hamada, Y. 2017. Teaching EFL learners shadowing for listening: Developing learners' bottom-up skills. New York: Routledge.

Kadota, S. 2012. Shadoingu to ondoku to eigoshutoku no kagaku [Science of shadowing, oral reading, and English acquisition]. Tokyo: Cosmopier Publishing Company.

Kadota, S. 2015. Shadowing, ondoku to eigo communication no kagaku. [Shadowing, repeating, and the mechanism of English Communication]. Tokyo: Cosmo Pier.

MEXT. 2003. Eigo ga tsukaeru Nihon-jin ikusei no tame no koudou keikaku [Action plan for educating global citizens with high English competence]. http://www.mext.go.jp/b_menu/shingi/chukyo/chukyo3/004/siryo/04031601/005 .pdf

Osuka, N. 2008. What factors affect Japanese EFL learners' listening comprehension? In K. Bradford Watts, T. Muller, M. Swanson (Eds.), JALT2007 Conference Proceedings. Tokyo: JALT.

Richards, J.C. 1983. Listening comprehension: Approach, design, procedure. TESOL Quaretrly, 17(2), 219-240.

Tamai, K. 2002. Listening ryoku kojo ni okeru shadowing no koka nit tsuite [On the effects of shadowing on listening comprehension]. Keynote lecture at the $3^{\text {rd }}$ Annual Conference of JAIS. Interpretation Studies 2, 178-192.

Tamai, K. 2005. Listening shidoho to shite no shadowing no koka ni kansuru kenkyu [Research on the effect of shadowing as a listening instruction method]. Japan: Kazama. 